\title{
触媒反応に期待される分子形状選択性*
}

\author{
内 島 俊 雄**
}

\author{
Shape Selectivity in Catalysis**
}

\section{Toshio UchiJimA*}

\begin{abstract}
Zeolites, crystalline aluminosilicates, have been widely used as unique catalysts in many petrochemical processes.

The first key to their activity is that the proton or multivalent cation-exchanged zeolites usually show extremely strong Brönsted acidity, which is essential for promoting many kinds of organic reactions of hydrocarbons, e. g. dehydration, polymerization, isomerization, alkylation, cracking and so on. The second key is that the anhydrous crystal has a large, regular pore structure, which lets it function efficiently as molecular sieves to sort out molecules, reactants and/or products. This aspect is called the shape selectivity in catalysis, for which the effective sige of pore opening is important.

In 1976, MTG (Methanol To Gasoline) process was reported on HZSM-5, which is very strong in Brönsted acidity, and has a zigzag pore channel of uniform size. This invention affords us the most typical shape selective reaction. Further extension of the idea is desired in the field of $\mathrm{C}_{1}$ chemistry to produce ethylene or propylene selectively from methanol.
\end{abstract}

\section{1. はじめに}

化学反応は, 何らかのかたちで触媒の作用を利用しているものが多い。しかも, 実用的なプロセ スで使われる触媒は, ほとんどが固体である。ところが, 触媒化学は, これまで鉱物学や結晶学と あまり密接な関係をもってきたとはいえない。

その理由としては, 物質の触媒としての性能を決めるのは, 1 義的にはその化学組成であり, そ の構造や組織は 2 義的なものと考えられることがあげられる。触媒としては, 同一組成物をできる だけ高表面積で結晶化度の低い状態に保つことが望ましいのであり,これは結晶化学者からみれば 興味のもてない対象であったであろう。そのなかで, 多孔性の結晶性アルミノケイ酸塩である一連 のゼオライトは, 特異な位置を占めている。複雑な細孔構造を有し, 結晶性であり, 高表面積を有 し，後述するようにすぐれた触媒作用を示す。鉱物学・結晶学と触媒化学の接点として相応しい題

\footnotetext{
* 1982年 6 月 3 日 日本鉱物学会30周年記念シンポジウムにおいて講演

** 筑波大学 物質工学系

Institute of Material Science, University of Tsukuba,

Sakura, Ibaraki 305
} 
材であろう。

1960 年に, はじめて合成ゼオライトのすぐれた触媒作用が報告されて以来, 触媒への利用の研究 がにわかに活潑となり，60 年代は第 1 期の黄金時代であった。その結果, 石油の接触分解や改質反 応に種々の合成ゼオライトが使われるようになり，工業的にも重要な位置を占めるようになった。 最近になって, ZSM-5 とよばれる新しい合成ゼオライトが，メタノールをガソリンに変える有効 な触媒であることを, Mobil Oil 社が公表し世界中の注目を集めた。このプロセスは, 昨今のエネ ルギー問題との関連で, 石油代替エネルギーの可能性をもつものとして重要であり，それを契機と してゼオライトの触媒化学的研究が，いま第 2 の黄金時代を迎えている。

こつでは, ゼオライトのどのような性質が触媒反応に利用されるのか, 触媒化学の分野で現在受 け容れられている考え方を，できるだけ分かりやすく招介することにしたい。

\section{2. 触媒化学的にみたゼオライトの性質}

ゼオライトは, 多孔性の結晶性アルミノケイ酸塩で, 触媒化学的に重要な特性は, (1)強い固体酸 性, (2)イオン交換性，(3)分子形状選択性，の 3 点に要約される。

\section{1. 強い固体酸性 ${ }^{1.2)}$}

ゼオライトは, $\left(\mathrm{SiO}_{2}\right)$ と $\left(\mathrm{AlO}_{2}\right)$ - の単位で示される四面体が頂点共有によって形成する 3 次元 ネットワークからなっている。骨格の $\mathrm{Si}^{+4}$ の一部を原子番号が一つだけ若い $\mathrm{Al}^{+3}$ が置換するとい うことは, $\left(\mathrm{AlO}_{2}\right)^{-}$単位が過鄱負電荷をもつことを意味し，それに見合ったカチオンが近傍に保持 されることになる。カチオンがアルカリ金属のようなイオン半径の大きな1価カチオンであれば, 特別の酸性度を示すことはない。図 1 に示すように, これを $\mathrm{NH}_{4}^{+}$イオンと交換（I）したあと加 熱 $\left(250 \sim 300^{\circ} \mathrm{C}\right)$ して $\mathrm{NH}_{3}$ を取り除くと, $\mathrm{H}^{+}$がカチオンサイトを占めたゼオライトが得られ，こ のものは強いB（ブレンステッド）酸性を示すょうになる（II）。さらに高温 $\left(\sim 500^{\circ} \mathrm{C}\right)$ に加熱す ると，脱水がす〉み， 3 配位の $\mathrm{Al}(\mathrm{IV})$ により $\mathrm{L}$ （ルイス）酸性を発現することになる。 $\mathrm{NH}_{4}{ }^{+}{ }$型 $^{+}$ ゼオライトを加熱することにより，はじめB酸性が発現し，ついでL酸性に移り変わるようすが図 2 に示される。B酸とL酸の相対量は，吸着ピリジンの赤外吸収スペクトルによって測定する方法<smiles>[NH3+][Si](O)(O)O[Si]([O-])(O)O</smiles>

( I) $\mathrm{NH}, \mathrm{Y}$<smiles>O[Si](O)(O)O[Si](O)(O)O</smiles>

(III)

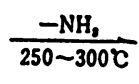

2

図 1 ブレンステッド酸点およびルイス酸点生成のモデル
(IV)

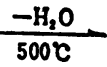

(II) H.Y<smiles>O[Al](O)O[Si](O)(O)O</smiles>

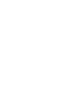




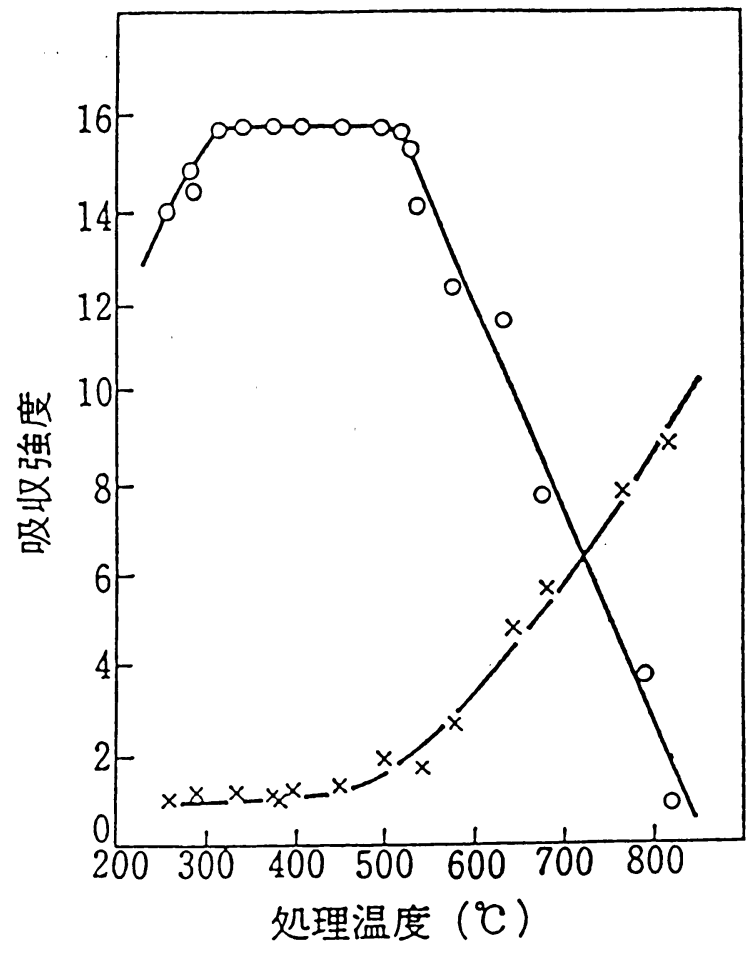

図 2 ブレンステッド酸点およびルイス酸点に吸着したピ リジンの吸収強度の処理温度依存性

○：ブレンステッド酸性, $\times$ : ルイス酸性

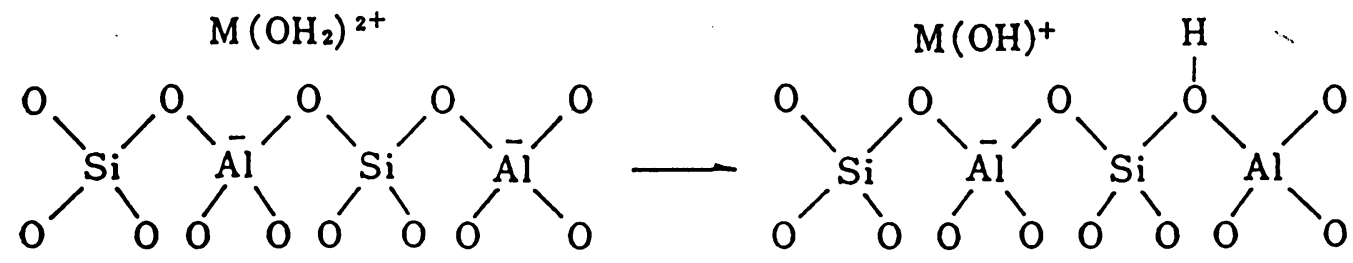

図 3 多洒カチオン交換ゼオライトにおけるプレンステッド酸点生成のモデル

がすでに確立している。さて, 古くから非晶質のシリカアルミナが強い固体酸性を示すことが知ら れているが，その酸性発現のメカニズムはほડ゙上と同様である。

H型（プロトン型）のゼオライトやさらに脱水のす〉んだゼオライトが, それぞれ B酸性, L酸 性を示すことは，上のとおり化学的に理解することができる。しかし，アルカリ土類金属のような 多価カチオンで交換したものも，強いB酸性を示すことが知られている。それは，図 3 のように, 2 ヶの $\left(\mathrm{AlO}_{2}\right)^{-}$単位の一方に $\mathrm{M}(\mathrm{OH})^{+}$が, 他方に $\mathrm{H}^{+}$が局在するような形をとり, 流の $\mathrm{H}^{+}$ある いは一-OH がB酸性を与えるものと考えられる。

酸性度には, 型 (B酸と L 酸) と強さと量の 3 特性がある。有機塩基の滴定による指示薬法, 赤外 


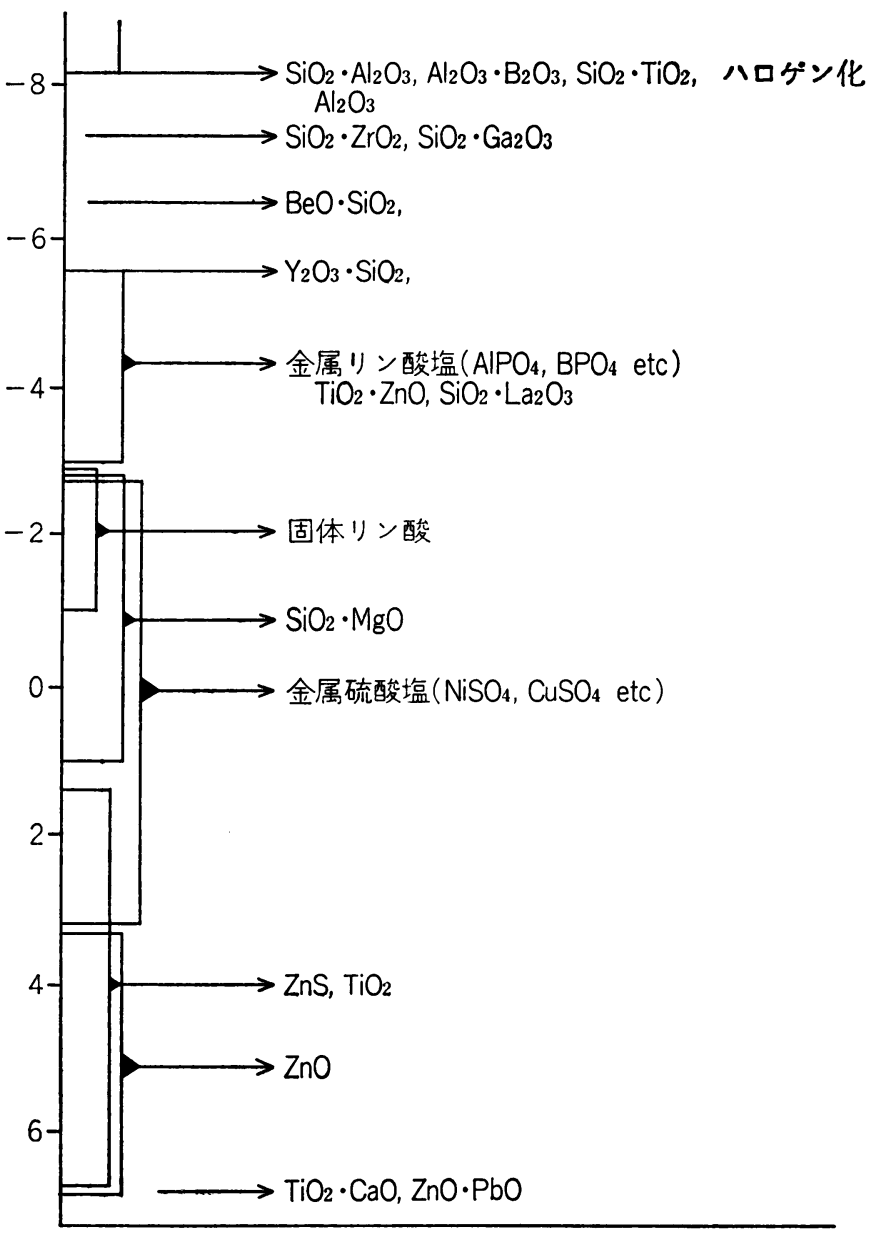

図4固体酸の酸強度の序列

吸収法（ピリジン吸着など），熱量測定などにより，古くからこれら酸特性の測定が行なわれてい て，いろいろな固体酸についてかなりょく分かっている。とはいっても，3 特性を一度に測定でき る万能の方法がないことと, いずれも大変な労力を要する方法であるために, 完全にデー夕が揃っ ているというわけにはいかないが，むかしからよく知られている種々な固体酸物質がどの程度の強 さをもつか，その序列を図 4 に示す ${ }^{3)}$ 。 $\mathrm{H}_{0}$ は酸強度を表すパラメータで, 負で大きいほど酸が強い ことを意味する。シリカアルミナなどは, 最も強い固体酸として位置づけられている。ちなみに $\mathrm{H}_{0}=-8$ は $90 \% \mathrm{H}_{2} \mathrm{SO}_{4}$ に相当しているが, シリカアルミナには $\mathrm{H}_{0}=-12.8\left(106 \% \mathrm{H}_{2} \mathrm{SO}_{4}\right)$ よりも 強い酸性点も存在するとされている。

ゼオライトの酸性度は, ゼオライトの種類, $\mathrm{Si} / \mathrm{Al}$ 比, イオン交換の種類と交換度, 処理温度な どにより大きく変化するが，H型または多価カチオン型で適当に処理されたものは，非常に強いB 酸点を多量に保持していることが，その一般的特徴であるといえる。HZSM-5 とシリカアルミナ $(\mathrm{SA}-1)$ の酸強度の分布を図 5 に比較する4)。図は, B酸だけに吸着すると考えられるジメチルピ 


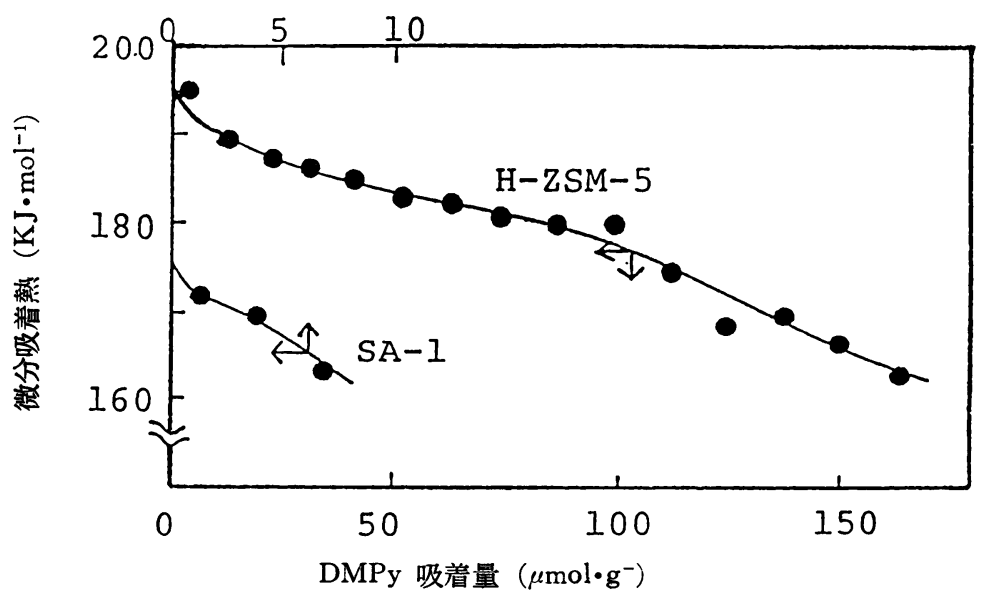

因 5 ジメチルピリジン (DMPy) の吸着熱量測定による酸強度分布 の比較 (673 k)

リジン (DMPy) の微分吸着熱を, 吸着量に対してプロットしたもので, B酸の強さ, 量ともに, HZSM-5 ガシリカアルミナにまさっている。

さて, B酸をもつ固体酸上でいろいろな有機化学反応が進行する。炭化水素のクラッキング, オ レフィンの異性化, 重合, 芳香族のアルキル化, 脱アルキル, トランスアルキル化, アルキル芳香 族の異性化, アルコールの脱水など，さむざまな反応があげられる。いずれの反応も， B酸点上で $\mathrm{H}^{+}$が付加したカルボニウムイオンを生成し, これを中間体として反応するという点で, 共通した 反応機構によっている。典型的な反応式を示すと，例えばつぎのように表される。

エタノールの脱水

$$
\mathrm{C}_{2} \mathrm{H}_{5} \mathrm{OH} \stackrel{\mathrm{H}^{+}}{\longrightarrow} \mathrm{C}_{2} \mathrm{H}_{3} \mathrm{O}^{+} \mathrm{H}_{2} \stackrel{-\mathrm{H}_{2} \mathrm{O}}{\longrightarrow} \mathrm{C}_{2} \mathrm{H}_{5}+\stackrel{-\mathrm{H}^{+}}{\longrightarrow} \mathrm{C}_{2} \mathrm{H}_{4}
$$

ブテンの異性化

$$
\stackrel{\mathrm{CH}_{3}}{\mathrm{CH}=\mathrm{CH}} \underset{\mathrm{CH}_{3}}{\stackrel{\mathrm{H}^{+}}{\longrightarrow}} \mathrm{CH}_{3} \stackrel{+}{\mathrm{C}} \mathrm{HCH}_{2} \mathrm{CH}_{3}
$$

$$
\stackrel{-\mathrm{H}^{+}}{\longrightarrow}\left\{\begin{array}{l}
\mathrm{CH}_{3} \quad \mathrm{CH}_{3} \\
\mathrm{CH}=\mathrm{CH} \\
\mathrm{CH}_{2}=\mathrm{CHCH}_{2} \mathrm{CH}_{3} \\
\mathrm{CH}_{3}-\mathrm{CH}_{2}=\mathrm{CH}_{2} \\
\quad \mathrm{CH}_{3}
\end{array}\right.
$$

アルキルベンゼンの異性化とクラッキング<smiles>[R]C1=CC([R])=[CH+]C1[R]</smiles> 


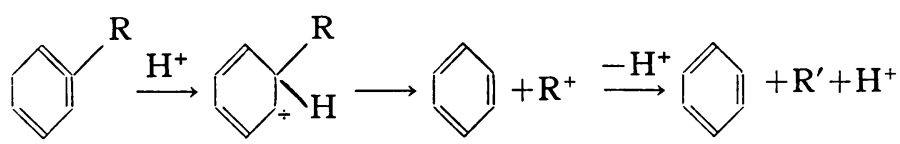

一般に, 酸型のゼオライトは,これらすべての反応に対して有効である。たよ゙し，酸点がありさ えすれば，これらの反応が進行するというわけにはいかない。B酸点の強度がもう一つの重要な因 子である。表 1 に, シリカアルミナの酸点を少しづつピリジンで被毒しながら，いろいろな反応に 対する触媒活性をしらべた結果が示される。強い酸点から順にピリジンで被毒されていくと考えら れるので, 強酸点を必要とする反応では, 少量のピリジンで活性が失なわれるのが分る。

表 1 ピリジン吸着による各種反応の転化率（\%）の変化

触媒 : シリカ・アルミナ, 反応温度 : $200^{\circ} \mathrm{C}$

\begin{tabular}{|c|c|c|c|c|c|}
\hline \multirow{4}{*}{$\begin{array}{c}\text { ピリシン畟着量 } \\
(\mathrm{mmol} / \mathrm{g})\end{array}$} & \multicolumn{3}{|c|}{ 反 } & \multicolumn{2}{|l|}{ 応 } \\
\hline & (1) & (2) & (3) & (4) & (5) \\
\hline & 脱水 & クラッキング (A) & $\begin{array}{l}\text { 二重結合移動拉上 } \\
\text { びシス・トランス } \\
\text { 舆性化 }\end{array}$ & クラッキング（B) & 骨格異性化 \\
\hline & $\stackrel{t-\mathrm{BuOH}}{\longrightarrow \mathrm{C}^{\prime}}$ & $\begin{array}{l}シ \text { シンフォレン } \\
\longrightarrow \mathrm{C} \text { ' など }\end{array}$ & $\begin{array}{l}\text { nーブテン } \\
\stackrel{\longrightarrow}{\longrightarrow} \text { 異性件 }\end{array}$ & $\stackrel{t-\mathrm{Bu} \phi}{\longrightarrow} \rightarrow \phi+\mathrm{C}^{\prime}$ & $\begin{array}{l}\text { インブテン } \\
\longrightarrow n \text {-ブテン }\end{array}$ \\
\hline 0 & \multicolumn{5}{|c|}{ すべて 100\% である. } \\
\hline 0.053 & $100 \%$ & 100 & 100 & 1 & tr \\
\hline 0.106 & 100 & 100 & 100 & $\operatorname{tr}$ & 0 \\
\hline 0.149 & 100 & 22 & $1 \sim 10$ & $\operatorname{tr}$ & 0 \\
\hline 0.289 & 100 & tr & $\operatorname{tr}$ & 0 & 0 \\
\hline 0.415 & 100 & tr & $\operatorname{tr}$ & 0 & 0 \\
\hline 0.531 & 12 & 0 & 0 & 0 & 0 \\
\hline
\end{tabular}

tr: 退跡を意味す万.

アルコールの脱水やオレフィンの二重結合移動などの反応は，弱いB酸上でも進行するが，パラ フィンの異性化やクラッキングにはきわめて強いB酸が必要である。例えば, $\mathrm{n}$-ペンタンの異性 化が，シリカアルミナやYゼオライト上で生起せず, $\mathrm{Si} / \mathrm{Al}$ 比の大きいHモルデナイト上で接触さ れるのは, 酸強度のためであると考えられている。あとに述べるメタノールの炭化水素への転化反 応についても，HZSM-5におけるきわめて強いB酸点の存在が重要な因子と考えられる。

\section{2. イオン交換性 ${ }^{2)}$}

ゼオライトのカチオンは, 容易に他のカチオンで交換することができる。この性質を利用して, 種々の遷移金属カチオンを均一に担持させ，その触媒作用を発揮させることができる。また，交換 した遷移金属カチオンを適当な条件で還元することにより，金属のクラスターまたは微粒子を担持 させることができ，ゼオライトがもつ酸性とあとに述べる形状選択性のほかに，これら金属の触媒 作用を加味した二元機能触媒をつくり出すことができる。Ni 担持エリオナイトによるセレクトホ ーミングや，ZSM-5 やモルデナイトに Ni または Pt を担持した触媒による脱ロウ法など，実用的 なプロセスにも応用されている。これらは，金属の作用により炭化水素を分解させる反応であるが， ゼオライトの分子ふるい作用により分子径の小さな直鎖炭化水素だけを選択的に分解するようにエ 夫された触媒である。組み合わせの妙により，ますます新しい触媒開発が期待されるし，金属粒径 
の制御など触媒化学的にもおもしろい一つの大きな分野になっている。しかし，ここではこれ以上 深入りをしないで，つぎの項にすすむことにする。

\section{3. 分子形状選択性 $2,6,10)$}

ゼオライトのもう一つの特徴は, $\left(\mathrm{SiO}_{2}\right)$ と $\left(\mathrm{AlO}_{2}\right)^{-}$-が連結してつくり出す 3 次元網目構造の中 に, さまざまな大きさの細孔が形成され, それらが 3 次元のチャンネル構造をつくり出すことであ る。そして, 表面積のほとんどすべてはこの細孔内表面積で占められるので, 触媒反応はこれら細 孔内で生起する。細孔は， $\left(\mathrm{SiO}_{2}\right)$ の 4, 6, 8, 10, 12 員環などの基本単位の連結によってつくられる 多面体で, その細孔径の大きさが通常の有機反応分子のそれと近いので, 分子の出入りに対して選 択的な機能を発揮する。そこで, 触媒化学の分野では, 入口細孔径の大きさによってゼオライトを 分類するのが好都合である。

1. Small-pore ゼオライト（菱フッ石，エリオナイト，ゼオライトAなど）； 8 員環の空をもち, $\mathrm{n}$-パラフィン (n-:ヘキサン : $4.3 \AA$ Å) を通すが, $\mathrm{i}$-パラフィン ((3-メチルペンタン:5.6 $\mathrm{A})$ や 芳香族分子 (トルエン : $5.0 \AA$ ) は通さない。

2. Intermediate-pore ゼオライト (ZSM-5, ZSM-11, シリカライトなど)；10 員環の窓をもち,

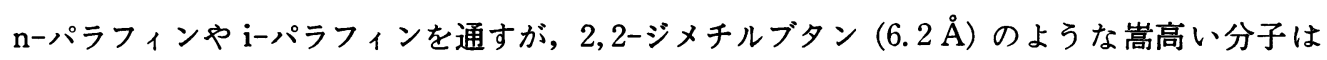
通さない。

3. Large-pore ゼオライト（モルデナイト，ホージャサイト，ゼオライトX, ゼオライトYな ど）；12 員環の窓をもち, n-パラフィンから 2,2-ジメチルブタンのような嵩高い分子まで通 過させる。

このように, 細孔入口径は, $\left(\mathrm{SiO}_{2}\right)$ のしっかりした多員環構造で規定されているが，細孔入口付 近にカチオンが存在する場合には，カチオンの大きさによってもある程度入口径をコントロールす ることができる。図 $6 に$ に, よく使われている各種ゼオライトの有効入口径を, 種々の分子の分子径 と対比して示してある。

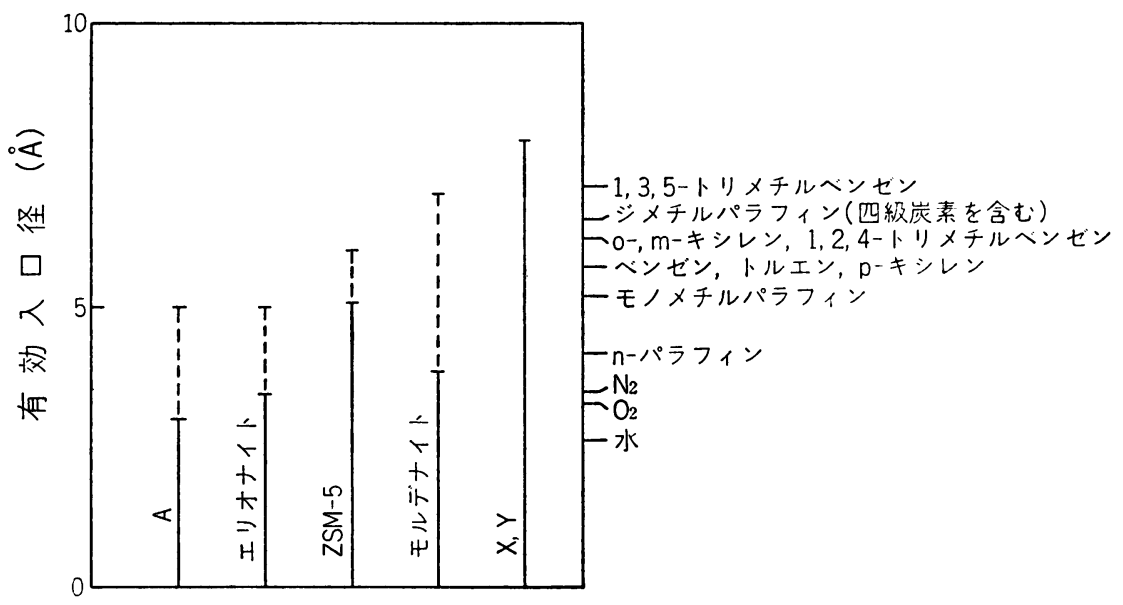

図 6 各種ゼオライトの有効入口径 点線はイオン交換により変化する範囲を示す。 
表 2 n-ヘキサンと 3-メチルペンタンの接触分解

\begin{tabular}{l|cc}
\hline \hline \multirow{2}{*}{ 触媒 } & \multicolumn{2}{|c}{ 転化率(\%) } \\
\cline { 2 - 3 } & n-ヘキサン & 3-メチルペンタン \\
\hline $\mathrm{CaA}$ & 9.2 & $<1$ \\
シリカ・アルミナ & 12.2 & 28 \\
\hline
\end{tabular}

反応温度 : $500^{\circ} \mathrm{C}$, 接触時間 : $7 \mathrm{sec}$

\begin{tabular}{|c|c|c|c|c|c|}
\hline \multicolumn{6}{|c|}{ ヘキサン類 } \\
\hline$C-C-C-C-C-C$ & $\begin{array}{c}C-C-C-C-C \\
C\end{array}$ & $\begin{array}{c}C-C-C-C-C \\
C\end{array}$ & $\begin{array}{c}C-C-C-C \\
C C\end{array}$ & & 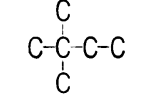 \\
\hline 0.71 & 0.38 & 0.22 & 0.09 & & 0.09 \\
\hline \multicolumn{6}{|c|}{ ヘプタン類 } \\
\hline$C-C-C-C-C-C-C$ & $\begin{array}{c}C-C-C-C-C-C \\
C \\
C\end{array}$ & $\begin{array}{c}C-C-C-C-C-C \\
C\end{array}$ & $\begin{array}{c}C-C-C-C-C \\
C C\end{array}$ & $\begin{array}{c}C-C-C-C \\
C \quad C\end{array}$ & $\begin{array}{c}C \\
C-C-C \cdot C-C \\
C \\
C\end{array}$ \\
\hline 1.0 & 0.52 & 0.38 & 0.09 & 0.05 & 0.17 \\
\hline
\end{tabular}

図 7 HZSM-5 触媒によるパラフィン異性体の分解反応 反応温度 : $340^{\circ} \mathrm{C}$, 図中の数字は相対的 1 次反応速度定数 を表す。

反応の場が細孔内壁にあって，そこへの分子の出入りが細孔入口径で規制されるために，これを 分子形状選択性として触媒反応に利用できるわけである。n-ヘキサンと3-メチルペンタンの接触 分解で, シリカアルミナ上では後者の方が反応性が大きい。2 級炭素をもつ3-メチルペンタンの方 が反応性が高いためである。しかし， $\mathrm{CaA}$ では，分子径の小さい $\mathrm{n}$-ヘキサンは細孔に侵入できる が，3-メチルペンタンは入口でふるいおとされるために，n-へキサンが選択的に反応することにな る。その関係が表 2 に示される。

2-メチルペンタンと 2,2-ジメチルブタンの競争吸着で, $\mathrm{H}$ モルデナイトでも2-メチルペンタン に高い選択性を示すが，HZSM-5 では 2-メチルペンタンのみが吸着する。n-オクタン，3-メチル ヘプタン，2,2,4-トリメチルペンタンの接触分解では, HY は分子形状に対する選択性を示さない

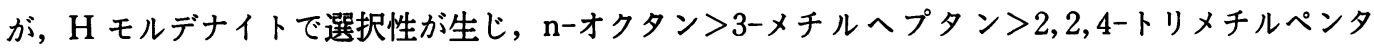
ンの反応序列となり，HZSM-5 でその選択性は非常に高くなる。図 7 には，ヘキサンおょびへプ タンの各異性体の HZSM-5 上での分解反応の活性を比較する。置換基の多い大きい分子ほど, 細 孔に入りにくく，活性の低いことがわかる。

反応する分子の大きさに対する選択性だけではなく，生成する分子が細孔を通過して気相に出る 
ことができるかどうかという，生成分子の大きさを規制するタイプの形状選択的反応についても， 多く知られている。つぎの項で述べるメタノールの転化反応は, その最も典型的な例である。

ゼオライトは, 強い固体酸性, イオン交換性, 分子形状選択性のすぐれた 3 特性のゆえに, 20 余 年の間, 触媒化学研究に手広く適用され, そして実用プロセスにも利用されてきた。そして,メタ ノールの炭化水素への転化反応は, 全く新しいタイプの反応で, ゼオライトの新たな局面を切り拓 いたものといえる。

\section{3. メタノールの炭化水素への転化反応 ${ }^{5,7 \sim 11)}$}

1976 年, Mobil Oil 社が, 新しいタイプの合成ゼオライト HZSM-5 がメタノールをガソリンに 転化（MTG (Methanol To Gasoline）プロセス) するのに有効であることを公表し，世の注目を集 めた。HZSM-5 は,

(1) 10 員環で規制された中間的な細孔径をもち，均等径のジグザグ構造のチャンネルをもつ（図 8),

(2) $\mathrm{SiO}_{2} / \mathrm{Al}_{2} \mathrm{O}_{3}$ 比がきわめて大きく, 疎水性である,

(3) 強いB酸性をもつ,

のが特徵で, とくに(1), (2)の点で従来多用されてきた種々のゼオライトとはかなり異なっている。 HZSM-5 は, メタノールの炭化水素への転化反応に高い触媒活性を示し, 得られる生成物には

(a) $\mathrm{C}_{11}$ 以上の炭化水素をほとんど生成しない,

(b) 脂肪族の炭化水素は分岐体が多い,

(c) 芳香族はほとんどアルキル化されている (トルエンとキシレンが主)，

などの特徴がみられる。このことは, 高オクタン価のガソリン成分だけが選択的に生成することを 意味し, 実用的にも大きな意味をもっている。固定床および流動床による反応試験の結果を表 3 に

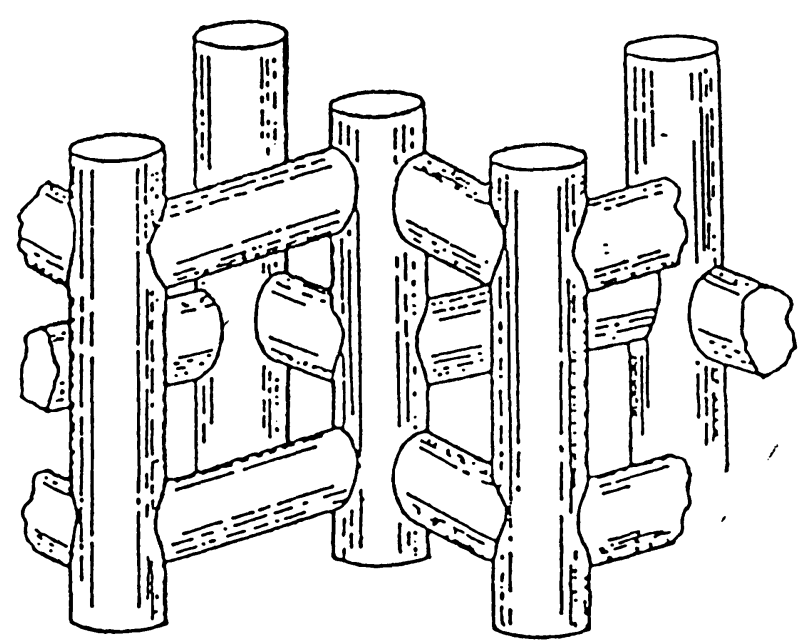

図 8 ZSM-5（代表的組成 $\mathrm{Na}_{2} \mathrm{Al}_{2} \mathrm{Si}_{94} \mathrm{O}_{192} \cdot 13 \mathrm{H}_{2} \mathrm{O}$ ) の細 孔チャンネル構造のモデル 
表 3 MTG プロセスによる生成物とその収率

\begin{tabular}{|c|c|c|}
\hline & 固定床 & 流動床 (4 BPD) \\
\hline 入口温度 ${ }^{\circ} \mathrm{F}$ & 680 & 775 \\
\hline 出口 " ${ }^{\circ} \mathrm{F}$ & 780 & \\
\hline 圧力 psig & 315 & 40 \\
\hline 循環比（モル比） & 9.0 & - \\
\hline 空間速度 WHSV & 2.0 & 1.0 \\
\hline \multicolumn{3}{|c|}{ 収率，供給メタノール基準の wt \% } \\
\hline メタノール+エーテル & 0.0 & 0.2 \\
\hline 炭化水素 & 43.4 & 43.5 \\
\hline 水 & 56.0 & 56.0 \\
\hline $\mathrm{CO}+\mathrm{CO}_{2}$ & 0.5 & 0.1 \\
\hline コーク他 & 0.2 & 0.2 \\
\hline 計 & 100.0 & 100.0 \\
\hline \multicolumn{3}{|l|}{ 炭化水素分布, wt \% } \\
\hline メタン+エチレン+エタン & 1.4 & 5.6 \\
\hline プロパン & 5.5 & 5.9 \\
\hline プロピレン & 0.2 & 5.0 \\
\hline イソブタン & 8.6 & 14.5 \\
\hline n-ブタン & 3.3 & 1.7 \\
\hline ブテン & 1.1 & 7.3 \\
\hline $\mathrm{C}^{5+}$ ガソリン & 79.9 & 60.0 \\
\hline 計 & 100.0 & 100.0 \\
\hline \multicolumn{3}{|l|}{ 製品分布， wt \% } \\
\hline ガソリン（アルキル化後） & 85.0 & 88.0 \\
\hline LPG & 13.6 & 6.3 \\
\hline 然料ガス & 1.4 & 5.6 \\
\hline 計 & 100.0 & 100.0 \\
\hline
\end{tabular}

示す。

MTG プロセスは，パイロットプラント試験の結果も順調で，ニュージーランドでは実用プラン トの建設がす〉められている。まだ試験的段階にあるとはいえ，天然ガスからメタノールを経て選 択的にガソリンが得られることは，エネルギー源の多様化という現下の要請に見合っており，その 推移が注目されるところである。

一方, この反応は新しいタイプの反応であるため, その反応機構や HZSM-5 の触媒化学的特性 について，現在基礎研究がさかんに行なわれている。メタノールの転化反応は，脱水によるジメチ ルエーテルの生成, さらに脱水によるエチレン等の低級オレフィンの生成, ついで高級オレフィン, イソパラフィン, 芳香族の生成, などの過程を経て順次進行することが確かめられている。この中 で, ジメチルエーテルから低級オレフィンを生成する段階（C-C 結合の生成）が，新しいタイプ の反応で, かつ最も困難なステップと考えられ，いったん低級オレフィンが生成すればそのあとの 
表 4 HZSM-34 によるメタノール転化反応

\begin{tabular}{|c|c|c|c|}
\hline 運転時間（(hrs.） & & $1 \sim 2$ & $11 \sim 12$ \\
\hline 温度プロフィル（ ${ }^{\circ} F ） \quad 0$ & & 655 & 654 \\
\hline \multirow[t]{4}{*}{ （塔頂からの深さ, インチ） } & $1 / 2$ & 693 & 693 \\
\hline & 1 & 700 & 705 \\
\hline & $11 / 2$ & 705 & 725 \\
\hline & $17 / 3$ & 706 & 735 \\
\hline WHSV & & 3.6 & 2.9 \\
\hline メタノール転化率（wt \%) & & 96.0 & 33.8 \\
\hline \multicolumn{4}{|c|}{ 生成物分率, wt（末反応物を除く） } \\
\hline ジメチルエーテル & & 1.9 & 57.2 \\
\hline 水 & & 55.5 & 33.8 \\
\hline 炭化水素 & & 42.6 & 8.9 \\
\hline \multicolumn{4}{|l|}{ 炭化水素分布，wt \% } \\
\hline メタン & & 1.8 & 7.5 \\
\hline エチレン & & 48.8 & 53.7 \\
\hline エタン & & 1.8 & 0 \\
\hline プロピレン & & 26.8 & 25.8 \\
\hline プロパン & & 7.1 & 0 \\
\hline ブテン & & 7.8 & 6.0 \\
\hline ブタン & & 3.3 & 4.5 \\
\hline ペンタン & & 2.6 & 2.6 \\
\hline
\end{tabular}

ステップは比較的速やかに進行するようである。C-C 結合生成のメカニズムについて，いくつか の提案があるが, 非常に強いB酸上でメチルカルボニウムイオン（通常は生成しにくい）を生成す ることが，この反応のキーポイントであろうとするのが，一つの有力な考え方である。

そうであれば, 強いB酸性が存在すれば, HZSM-5 ならずともメタノールから炭化水素が生成 すると期待されるが，実際に $\mathrm{HY}$ ゼオライト， $\mathrm{H}$ モルデナイト，ヘテロポリ酸などで類似の反応 が進行することがわかった。たぐし，HZSM-5 では生成物がほとんどガソリン成分だけであるの に, HY ゼオライトやHモルデナイトではもっと重い炭化水素成分が生成し，ヘテロポリ酸では芳 香族化合物がほとんど生成しないなど，生成物分布においてかなり相異しているし，活性の持続性， 耐被毒性においても HZSM-5 が圧倒的にすぐれている。

したがって，HZSM-5 のとくにすぐれている点は，単に強いB酸点の作用だけにあるのではな い。特徵の一つは形状選択性である。 $\mathrm{C}_{11}$ 以上の炭化水素を与えない上記 (a) の特徴は, 10 員環 の窓によって規定される入口細孔径が，生成分子の大きさを規制することによるもので，上記(1)の 構造上の特性によっている。第二の特徴は,コーキングによる被毒が少ないことで，これもまた構 造上の特性による。大きな細孔径をもつものや細孔中に大きなケージをもつものでは，芳香族縮合 環の生成がす〉み，これがコーキングによる失活に導くものと考えられるのに対し，HZSM-5 で は，中間的な適当な入口細孔径をもつだけでなく，均等径のジグザグチャンネル構造からなるため に，大きな芳香族縮合環を生成する空間がなく，コーキングによる被毒を受けにくいものと考えら 
れる。触媒設計の上できわめて示唆的な点である。第三の特徴は, 生成する $\mathrm{H}_{2} \mathrm{O}$ による被毒が少 ないことで，これは HZSM-5 の疎水性のゆえである。

MTG プロセスに関連して, メタノールをエチレン, プロピレン等の低級オレフィンに選択的に 転化し, 新しいルートで石油化学工業の基本原料を得ようとする試みがなされている。これは,わ が国の国家プロジェクトである $\mathrm{C}_{1}$ 化学の重要な目的の一つになっている。HZSM-5 と同じような 反応を行なわせながら，もっと細孔を絞ることで，エチレンなどの小分子で反応を止めることがで きはしないか，というのが試みの一つの方である。表 4 に示されるように，エリオナイトとオフ レタイトの混合型構造をもち, 小細孔ゼオライトに分類される HZSM-34で, 低級オレフィンが高 い選択性で得られているが, 経時的な活性劣化が著しい。HZSM-34 は, 小さな細孔入口径をもつ が，同時にチャンネルの途中に大きな空洞をもつので，そこでコーキングが生じ，失活するものと 思われる。均等な小細孔チャンネルだけをもつゼオライトが得られれば，大きな期待がもてそうで ある。

\section{4. おわりに}

わが国では，学際的という言葉が多用される割には，異なる専門間の協力が育ちにくかったよう に思う。筆者の専門とする担持金属触媒の狭、分野でみても，欧米では一流の触媒学者が一流の物 理学者と協同してすぐれた成果をあげていることが多く，とても歯が立たないと思わされることが しばしばある。

本稿の依頼を受けたとき, 鉱物学・結晶学と触媒化学の間の仲介者として多少ともお役に立てれ ばと考え, 両者の接点となるに相応しい話題としてゼオライトをとり上げて, その触媒化学的側面 を招介させていただくことにした次第である。知られていることのエッセンスとそこでの考え方を， できるだけ分かりやすくと考えてまとめてみたつもりではある。いま, 触媒化学の分野では, 強酸 性をもち, かつ任意の大きさで任意のつながりをもつ細孔チャンネル構造が得られないかと, 強く 要望されている。学際的協力によって，世界に先がけてその実現をみたいものである。

本稿をまとめるにあたり，下記の総説を参考にさせていただいた。主として使わせていただいた 文献番号は本文中各項毎に付記致しました。こつに，各総説の著者の方々に深くお礼を申し上げま す。

\section{文献}

1. 牧島ら, 近代工業化学 8。触媒工業化学, p. 69 (1971)。

2. 原, 高橋編, ゼオライト一基礎と応用 (1975)。

3. 田部, 特別講義予稿 (東大工), (1977)。

4. 武 (東大工), 私信

5. 八嶋, 化学と工業, 34 (12), 897 (1981)。

6. 八嶋, 難波, 化学, 36 (4), 280 (1981)。

7. 小野, 難波, 八嶋, 触媒, 21 (5), 356 (1979)。

8. 小野, ヘ่トロテック, 3 (11), 1039 (1980)。

9. 松浦, 化学と工業, 32 (12), 918 (1679)。 
10. 新, 高谷, $\mathrm{C}_{1}$ 化学工業技術集成（サイエンスフォーラム社), 488 (1981)。

11. 小野, 同上, 516 (1981)。

\section{〔討〔論〕}

須藤俊男：地質時代において。天然のゼオライトの交換イオンがプロトンによって代表された時期が存在した と考えなければならないか。

内 島：カルシウム型は充分強い固体酸である。本講演では, プロトンで代表した図式を使って、理解を促し たものであり，地質時代の産状を規定したものではない。 